\title{
Improving the nutritive value of olive pomace by solid state fermentation of Kluyveromyces marxianus with simultaneous production of gallic acid
}

\author{
Shadia A. Fathy ${ }^{1} \cdot$ Abeer E. Mahmoud $^{2} \cdot$ Mona M. Rashad $^{2} \cdot$ Magda K. Ezz $^{1} \cdot$ Amira T. Mohammed $^{2}$
}

Received: 5 September 2017 / Accepted: 28 January 2018 / Published online: 5 February 2018

(c) The Author(s) 2018. This article is an open access publication

\begin{abstract}
Purpose Olive oil industry is a growing industrial sector in Mediterranean countries. Unfortunately, about 30-35\% of total olive weight is discarded as olive pomace (OP), a highly environmental-polluting solid waste.OP is mostly used for composting and production of animal feed; nevertheless, the high oil content, phenolic compounds and fiber contents in addition to its low protein content represent major obstacles for both applications. So, the present study was conducted to evaluate the role of solid state fermentation (SSF) in OP using Kluyveromyces marxianus NRRL Y-8281 yeast on the chemical composition and tannin content of OP in a trial for its bioconversion into a value-added animal feed.

Methods Chemical composition, nutritive and energetic values, tannin and gallic acid contents of unfermented and fermented olive pomace were investigated.

Results The fermentation altered the chemical composition of OP, so that crude fiber was decreased by $8.56 \%$, while crude protein, fat and carbohydrate contents were increased by $2.74,2.63$ and $3.57 \%$, respectively. Moreover, the effect of fermentation on cell wall constituents, gross energy, digestible energy, total digestible nutrients and digestible crude protein was evaluated. Furthermore, HPLC analysis revealed that K. marxianus mediated fermentation of OP resulted in a sharp decrease in tannin content by $96.75 \%$ with 2.8 times increase in gallic acid concentration.

Conclusion SSF of OP by K. marxianus does not only eliminate the environmental pollution resulting from its accumulation, but also presents a new eco-friendly valorization technique which leaves OP with an altered chemical composition allowing its use as animal feed or compost.
\end{abstract}

Keywords Olive pomace $\cdot$ Solid state fermentation $\cdot$ Kluyveromyces marxianus $\cdot$ Nutritive value $\cdot$ Gallic acid

\section{Introduction}

Olive oil industries play an important economic role in Mediterranean countries. Considering a three phase decanter system (the most widely employed method for virgin olive oil production), two major by-products are generated, a solid residue (30\%) known as olive pomace (OP) (also known as orujo and olive cake $(\mathrm{OC})$ ) which consists of olive skin, pulp

Abeer E. Mahmoud

ab_essam@yahoo.com

1 Biochemistry Department, Faculty of Science, Ain Shams University, Cairo, Egypt

2 Biochemistry Department, Division of Genetic Engineering and Biotechnology Researches, National Research Centre, Dokki, Giza 12622, Egypt and pit, in addition to significant residual oil content, and a liquid waste (50\%) known as olive mill waste water (also known as alpechin) which consists of olive fruit tissue water, washing water and water added for centrifugation (Borja et al. 2006; Dermeche et al. 2013).

It is estimated that the world annual production of OP is 2,881,500 tonnes/year (Nunes et al. 2016). This represents a huge problem for olive oil producing countries, since this vast amount of waste cannot be stored in its original form for extended time due to its high water and significant oil contents that cause rapid deterioration and rancidity often after 4-5 days of its production, as a result, OP is spread on farm lands resulting in serious negative environmental impact regarding soil, underground water and air problems (Brlek et al. 2012).

Three phase OP is a heterogeneous matrix with a chemical composition that differs greatly among different 
producers (Christoforou and Fokaides 2016). OP is quite rich in water (30-50\%) and contains a substantial amount of residual oil (2-4\%) (Azbar et al. 2004). It is also characterized by high fiber (cellulose, hemicellulose, lignin and pectines) and low protein contents. In addition, it is rich in fat, mostly polyunsaturated fatty acids (Ramachandran et al. 2007; Molina-Alcaide and Yáñez-Ruiz 2008; Lafka et al. 2011). The ash content ranges between 1.7 and $4 \%$ and major elements present in OP are potassium followed by calcium, magnesium and sodium (Aliakbarian et al. 2011). Despite its variable composition, fibers followed by fat and protein remain the main constituents of OP (Christoforou and Fokaides 2016). OP is a ligno-cellulosic organic material which has low digestibility and energy content in addition to having high tannin content (Al-Masri and Guenther 1999).

Several practices (in particular, composting and animal feed production) have been introduced for disposal and utilization of OP aiming to reduce the environmental-polluting load with concomitant production of value-added bio-products (Cossu et al. 2013).

Low soil organic matter can lead to limited soil fertility and productivity followed by soil degradation. Thus, the periodic addition of organic fertilizers is strongly recommended to restore soil productivity (López-Piñeiro et al. 2011). Generally, natural fertilizers are more preferred than synthetic ones. Having significant contents of organic matter, nitrogen, potassium and phosphorus, OP is considered as a potent organic amendment that improves many soil properties, restores crops productivity and improves the soil nutrient level (Abu-Zreig and Al-Widyan 2002). Raw OP can be applied directly to soil as an organic amendment (Kavdir and Killi 2008). However, the residual oil contained in it results in increased soil hydrophobicity and decreased water retention and infiltration rate. Moreover, due to the high content of phenolic and phytotoxic compounds, utilization of raw $\mathrm{OP}$ as soil amendment for long time results in accumulation of toxicants in soil with detectable negative effects on plants in addition to land, ground water and surface water contamination (Lopes et al. 2016).

Livestock production in Mediterranean countries is constricted by the scarcity and fluctuating quantity and quality of the feed supply to animals. Agro-industrial residues can serve as alternative sources for livestock providing an economic and eco-friendly method for their disposal and recycling (Molina-Alcaide and Yáñez-Ruiz 2008). However, utilization of OP as animal feed additive is limited due to its low protein content, high phenolic compounds content and high fiber content which renders OP unpalatable and poorly digestible for ruminants. Moreover, the significant amount of energy contained in OP represented by the cellulose (14-26\%) is locked in ligno-cellulosic complex and thus it is inaccessible to ruminal microbes for degradation.
Consequently, pre-treatment of OP before animal consumption is necessary to eliminate its toxicity and upgrade its nutritional value (Weinberg et al. 2008). Bioconversion of OP through solid state fermentation (SSF) may represent an excellent pre-treatment strategy (Neifar et al. 2013). SSF is defined as the microbial growth on solid support in the lack or near absence of free water. However, the support must possess enough moisture to sustain microbial growth and metabolism (Pandey 1991). Several researches dealing with SSF of OP using fungal strains have been conducted allowing its use as animal feed additive for both ruminants (cattle, sheep, goats and camels) and poultry (Neifar et al. 2013; Fadel and El-Ghonemy 2015).

The aim of the present work was to evaluate the role of SSF in OP using Kluyveromyces marxianus NRRL Y-8281 yeast on the chemical composition and tannin content of $\mathrm{OP}$ in a trial for its bioconversion into a value-added animal feed.

\section{Materials and methods}

\section{Olive pomace waste}

OP was provided during its harvesting season by a local olive-pressing factory (three phase decanter system), located in Al-Arish, North Sinai, Sinai Peninsula, Egypt. It was stored at $4{ }^{\circ} \mathrm{C}$ till used.

\section{Chemicals}

Gallic acid was obtained from Bio Basic Canada INC (Markham Ontario, Canada). Code No. GB0476. Tannic acid was obtained from Panreac AppliChem (Castellar del Valles, Barcelona, Spain). Code No. 141065. All other chemicals and reagents used in this study were of analytical grade and purchased from Sigma-Aldrich Chemical Co. (St. Louis, MO, USA).

\section{Microorganism}

The generally regarded as safe (GRAS) yeast, Kluyveromyces marxianus NRRL Y-8281 used in this study was obtained from Agricultural Research Service, Peoria, Illinois, USA.

\section{Adaptation and inoculum preparation of the microorganism}

The yeast strain was streaked on YME medium with agar (Wickerham 1951) for $48 \mathrm{~h}$ at $30^{\circ} \mathrm{C}$. The stock culture was stored at $4{ }^{\circ} \mathrm{C}$ and sub-cultured every 4 weeks, then stored at $4{ }^{\circ} \mathrm{C}$. A loop of the culture was inoculated in $50 \mathrm{ml}$ of sterile 
inoculum medium (composed of the stock medium without agar), then incubated on controlled incubator shaker (New Brunswick Scientific, USA) at $150 \mathrm{rpm}$ for $24 \mathrm{~h}$ at $30^{\circ} \mathrm{C}$.

\section{Solid state fermentation}

For SSF, an aliquot of $1 \mathrm{ml}$ of each inoculum containing about $10^{8}$ cells $/ \mathrm{ml}$ was inoculated in $250 \mathrm{ml}$ Erlenmeyer flasks containing $5 \mathrm{~g}$ of sterilized OP (sterilized at $121^{\circ} \mathrm{C}$ for $20 \mathrm{~min}$ at $15 \mathrm{psi}$ ). Incubation was done at static incubator for $48 \mathrm{~h}$ at $45^{\circ} \mathrm{C}$ (Fathy et al. 2017).

\section{Chemical analysis of unfermented (UFOP) and fermented (FOP) olive pomace}

Chemical analysis of unfermented and fermented OP was done as described by AOAC (1997) method.

The moisture, ash, crude protein (CP) and crude fat contents of UFOP and FOP were determined in accordance with the AOAC (1997). Crude protein determination involved the use of routine Kjeldhal nitrogen assay $(\mathrm{N} \times 6.25)$. Total carbohydrate content was determined using the phenol-sulfuric acid method of Dubois et al. (1956). Cell wall constituents including neutral detergent fiber (NDF), acid detergent fiber and acid detergent lignin were determined according to Goering and Van Soest (1970) and Pv et al. (1991). Hemicellulose was calculated as the difference between NDF and ADF, whereas cellulose was the difference between ADF and ADL. Gross energy ( $\mathrm{kcal} / \mathrm{kg} \mathrm{DM}$ ) was calculated according to Blaxter (1968) where, each $g$ crude protein $=5.65 \mathrm{kcal}, \mathrm{g}$ fat $=9.40 \mathrm{kcal}$ and $\mathrm{g}$ (crude fiber and carbohydrate $)=4.15 \mathrm{kcal}$. Digestible energy $(\mathrm{kcal} /$ $\mathrm{kg}$ DM) was calculated according to NRC (1977) where, digestible energy $(\mathrm{DE})=$ gross energy $\times 0.76$. Total digestible nutrients (\%) was calculated according to NRC (1977) where, total digestible nutrients $\%=$ digestible energy/44.3. Digestible crude protein (\%) was calculated according to NRC (1977) where, digestible crude protein $(\%)=0.85$ $X 1-2.5$. Where $X 1=$ crude protein\% on DM basis.

\section{High-performance liquid chromatography analysis}

\section{Preparation of unfermented and fermented culture filtrates}

Culture filtrates were prepared by extracting the samples with eightfold (v/w) acetate buffer $(0.02 \mathrm{M}, \mathrm{pH} 5.5)$ by shaking $(200 \mathrm{rpm})$ at $30{ }^{\circ} \mathrm{C}$ for $60 \mathrm{~min}$. The resultant slurry was centrifuged at $10,070 \times g$ for $15 \mathrm{~min}$ at $4{ }^{\circ} \mathrm{C}$. Finally, the extracts were collected and considered as a source of tannic and gallic acids.
Analysis of unfermented and fermented culture filtrates

Tannic and gallic acids were estimated in both UFOP and FOP culture filtrates using HPLC technique. Aliquots were withdrawn and filtered through a $0.2 \mu \mathrm{m}$ membrane then subjected to HPLC analysis.

\section{HPLC system specifications}

All samples were analyzed by HPLC system Agilent 1100 series (Waldborn, Germany) equipped with variable wave length detector (G1314A), G1311A quaternary pump, G1322A degasser, G1329A thermostated autosamples and Zorbax 300SB C18 column (Agilent Technology, USA). Ten microliters of each sample and standard were injected and eluted at room temperature with water: methanol (80:20) as a mobile phase at a flow rate of $1 \mathrm{ml} / \mathrm{min}$. Detection was carried out at $272 \mathrm{~nm}$. Standard solutions $(3 \mathrm{mg} / \mathrm{ml})$ and $(2 \mathrm{mg} /$ $\mathrm{ml})$ for tannic and gallic acid, respectively, were analyzed to compare results.

\section{Data statistical analysis}

Data were expressed as mean \pm standard error and analyzed statistically using independent sample $t$ test for comparison between the fermented and unfermented olive pomace groups. Differences were considered significant at $P<0.05$.

\section{Results and discussion}

The chemical composition of UFOP and FOP was estimated and presented in Table 1. The moisture content of UFOP was found to be $35 \%$ which was approximately similar to the ratio of $30 \%$ reported by Uribe et al. (2013). Also,

Table 1 Chemical analysis of unfermented (UFOP) and fermented (FOP) olive pomace

\begin{tabular}{lcr}
\hline Item & \multicolumn{2}{l}{ Pomace } \\
\cline { 2 - 3 } & UFOP & FOP \\
\hline Moisture content $(\%)$ & $35.00 \pm 0.12^{\mathrm{b}}$ & $35.84 \pm 0.05^{\mathrm{a}}$ \\
Chemical analysis (\%) on dry matter basis & \\
Organic matter & $93.52 \pm 0.12$ & $93.90 \pm 0.19$ \\
Crude protein & $10.05 \pm 0.02^{\mathrm{b}}$ & $12.79 \pm 0.11^{\mathrm{a}}$ \\
Crude fiber & $42.60 \pm 0.11^{\mathrm{a}}$ & $34.04 \pm 0.06^{\mathrm{b}}$ \\
Fat content & $13.62 \pm 0.05^{\mathrm{b}}$ & $16.25 \pm 0.03^{\mathrm{a}}$ \\
Carbohydrate content & $27.25 \pm 0.06^{\mathrm{b}}$ & $30.82 \pm 0.01^{\mathrm{a}}$ \\
Ash content & $6.48 \pm 0.05^{\mathrm{a}}$ & $6.10 \pm 0.06^{\mathrm{b}}$ \\
\hline
\end{tabular}

Values are given as mean \pm standard error of three batches

Mean bearing different superscripts in the same raw are significantly different $(P<0.05)$ 
the crude protein was found to be $10.05 \%$ on dry matter basis which is close to the ratio 9.5\% reported by Fadel and El-Ghonemy (2015). Uribe et al. (2014a) stated crude protein ratio of 7.64\%, while Neifar et al. (2013) reported lower protein content (6.5\%). In addition, the crude fiber was found to be $42.6 \%$ on dry matter basis. This result is in accordance with that conducted by Uribe et al. (2013). Crude fiber ratios of $40,40.72$ and $33 \%$ were reported by Ramachandran et al. (2007), Brlek et al. (2012) and Fadel and El-Ghonemy (2015), respectively. Besides, the crude fat was found to be $13.62 \%$ on dry matter basis which was higher than that reported by Uribe et al. (2013), (2014a) and Fadel and El-Ghonemy (2015) stating crude fat ratio of 8.19, 10.31 and $5.7 \%$, respectively. But, this result was lower than that reported by Vera et al. (2009) who recorded a ratio of $16.5 \%$. Moreover, the carbohydrate content of UFOP was found to be $27.25 \%$ on dry matter basis which was lower than the carbohydrate content $(77.99 \%)$ reported by Uribe et al. (2014b). Finally, the ash content was found to be $6.48 \%$ on dry matter basis. This result is in accordance with that reported by Uribe et al. (2014a), (2014b) and (2015), and nearly in the same range of Neifar et al. (2013) and Fadel and El-Ghonemy (2015) who reported 7\% ash content, while Uribe et al. (2013) reported 5.47\% ash content. Cell wall constituents (NDF, ADF, ADL, hemicellulose and cellulose) values were found to be 56.91, 48.28, 8.74, 8.63 and $39.54 \%$, respectively (Table 2). Neifar et al. (2013) reported ratios of $59,45,31,14.1$ and $14.3 \%$ for NDF, ADF, ADL, hemicellulose and cellulose, respectively. And, ratios of 62 and $48 \%$ were estimated for NDF and ADF, respectively, by Fadel and El-Ghonemy (2015).

The variation in the chemical composition of OP reported by different authors can be attributed to the difference in olive variety, cultivation conditions (cultivation soil, geography of cultivation soil and use of pesticides and fertilizers), climatic conditions, harvesting conditions (the degree of ripening, harvesting time and system) and the applied oil extraction process (Doymaz et al. 2004; Brlek et al. 2012;

Table 2 Cell wall constituents of unfermented (UFOP) and fermented (FOP) olive pomace

\begin{tabular}{lrr}
\hline Constituent (\%) & \multicolumn{2}{l}{ Pomace } \\
\cline { 2 - 3 } & \multicolumn{1}{l}{ UFOP } & \multicolumn{1}{l}{ FOP } \\
\hline Neutral detergent fiber (NDF) & $56.91 \pm 0.01^{\mathrm{a}}$ & $51.29 \pm 0.63^{\mathrm{b}}$ \\
Acid detergent fiber (ADF) & $48.28 \pm 0.13^{\mathrm{a}}$ & $40.48 \pm 0.05^{\mathrm{b}}$ \\
Acid detergent lignin (ADL) & $8.74 \pm 0.02^{\mathrm{a}}$ & $7.29 \pm 0.11^{\mathrm{b}}$ \\
Hemicellulose & $8.63 \pm 0.08^{\mathrm{b}}$ & $10.81 \pm 0.07^{\mathrm{a}}$ \\
Cellulose & $39.54 \pm 0.03^{\mathrm{a}}$ & $33.19 \pm 0.06^{\mathrm{b}}$ \\
\hline
\end{tabular}

Values are given as mean \pm standard error of three batches

Means bearing different superscripts in the same raw are significantly different $(P<0.05)$
Uribe et al. 2013, 2014a, 2014b, 2015; Christoforou and Fokaides 2016).

Bioconversion of OP into a better-quality feed using SSF could be an alternative to chemical and physical treatment for enhancing its quality for microbial fermentation in rumen. SSF of OP using $K$. marxianus resulted in an increase in crude protein by $2.74 \%$, changing it from $10.05 \%$ for UFOP to $12.79 \%$ for FOP. This can be attributed either to the increased biomass or the secretion of enzymes into the fermented medium (Fadel and El-Ghonemy 2015). The increased protein content suggests that the treated substrate is a good protein source for livestock (Neifar et al. 2013; Fadel and El-Ghonemy 2015). Also, a decrease of ash and crude fiber content by 0.38 and $8.56 \%$, respectively, was observed after fermentation. The reduction in the crude fiber content indicates an increased digestibility of the resultant substrate (Neifar et al. 2013). In addition, the biodegradation of OP using $K$. marxianus resulted in an increase in carbohydrate content by $3.57 \%$ comparing to UFOP. The increased carbohydrate content can partially be attributed to the degradation of polysaccharide compounds which was associated with an increase in reducing sugars (Neifar et al. 2013). Increased carbohydrate content is an additional advantage besides the reduction of fiber content in the improvement of biomass quality through biological treatment as reported by Jahromi et al. (2011). Moreover, the crude fat was increased by $2.63 \%$ over the UFOP which is similar to the finding of Fadel and El-Ghonemy (2015) when growing Aspergillus oryzae FK-923 on OP.

Results in Table 2 showed that FOP expressed less cell wall constituents than UFOP as exhibited by the decrease of NDF, ADF, ADL and cellulose by 9.87, 16.16, 16.59 and $16.06 \%$, respectively. Fadel and El-Ghonemy (2015) reported a reduction in NDF and ADF by 28.06 and 32.08\%, respectively. While, Neifar et al. (2013) reported a reduction in NDF, ADF and ADL by 23, 14 and $11 \%$, respectively,

Table 3 Energetic and nutritive values of unfermented (UFOP) and fermented (FOP) olive pomace

\begin{tabular}{lrr}
\hline Item & \multicolumn{2}{l}{ Pomace } \\
\cline { 3 - 3 } & UFOP & \multicolumn{1}{l}{ FOP } \\
\hline Energetic values & & \\
Gross energy (kcal/kg DM) & $4747 \pm 3.28^{\mathrm{b}}$ & $4942 \pm 7.08^{\mathrm{a}}$ \\
Digestible energy (kcal/kg DM) & $3608 \pm 2.49^{\mathrm{b}}$ & $3756 \pm 5.38^{\mathrm{a}}$ \\
Nutritive values & & \\
Total digestible nutrients (TDN) (\%) & $81.44 \pm 0.56^{\mathrm{b}}$ & $84.78 \pm 0.12^{\mathrm{a}}$ \\
Digestible crude protein (DCP) (\%) & $6.04 \pm 0.01^{\mathrm{b}}$ & $8.37 \pm 0.10^{\mathrm{a}}$ \\
\hline
\end{tabular}

Values are given as mean \pm standard error of three batches

Means bearing different superscripts in the same raw are significantly different $(P<0.05)$ 


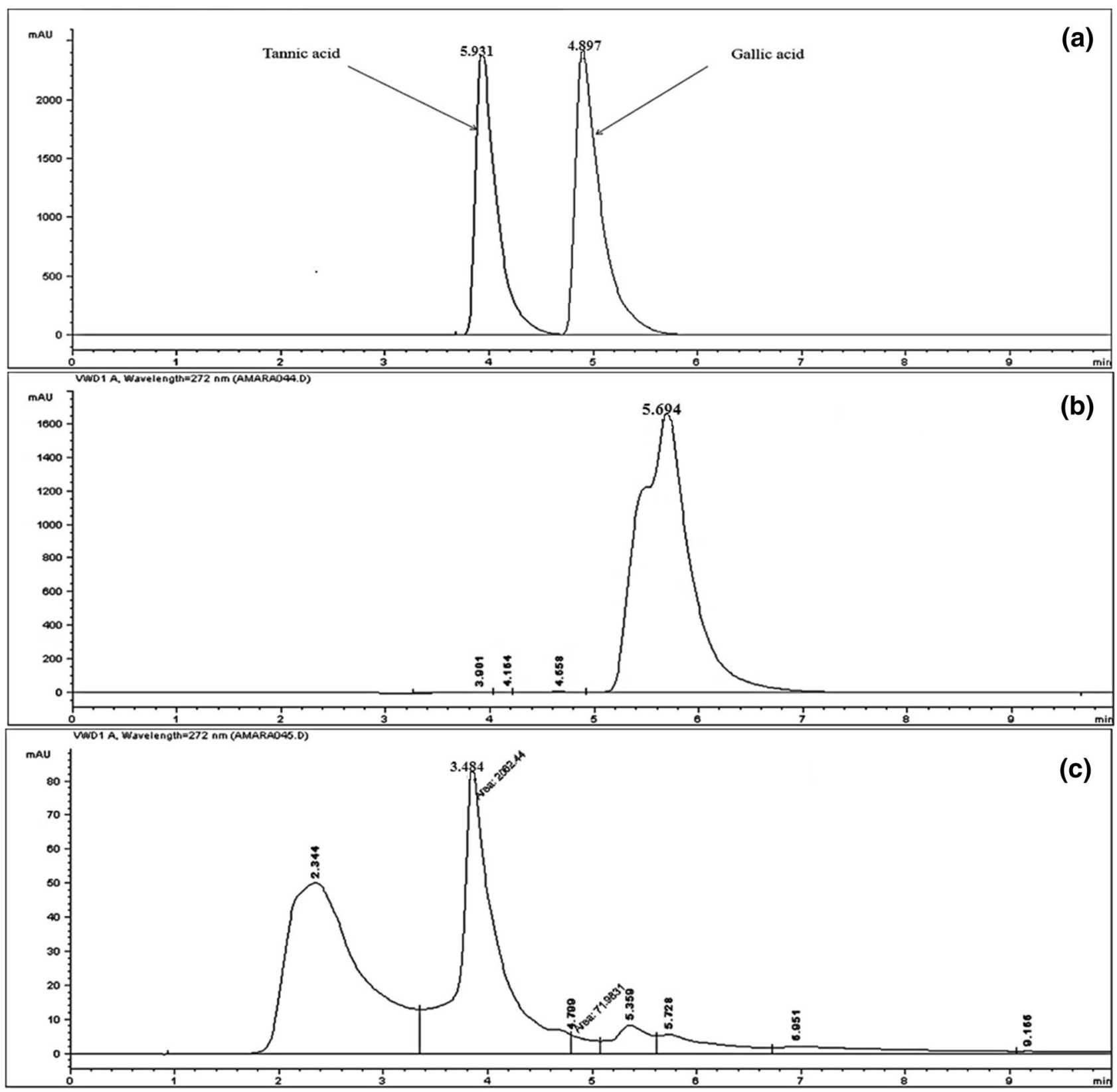

Fig. 1 Typical HPLC chromatograms of tannic acid and gallic acid standards (a), UFOP filtrate (b) and FOP filtrate (c)

when OP was utilized as a solid support for the SSF of Fomes fomentarius.

Table 3 shows the energetic and nutritive values of UFOP and FOP. The gross energy of UFOP was found to be 4747 (kcal/kg DM) which was higher than the value 4200 (kcal/ kg DM) reported by Fadel and El-Ghonemy (2015). Results showed that fermentation of OP by $K$. marxianus increased the gross energy up to 4942 ( $\mathrm{kcal} / \mathrm{kg} \mathrm{DM})$. While, Fadel and El-Ghonemy (2015) conducted an increase up to 4320 (kcal/ $\mathrm{kg} \mathrm{DM})$ after fermentation. In addition, results showed that fermentation of OP by K. marxianus increased the digestible energy (from 3608 to 3756 ( $\mathrm{kcal} / \mathrm{kg} \mathrm{DM}$ ), total digestible nutrients (from 81.44 to $84.78 \%$ ) and digestible crude protein (from 6.04 to $8.37 \%$ ).

Tannins are the second most abundant group of phenols in nature and they are considered as a plant's secondary metabolites, as they do not have a direct role in plant metabolism. Instead, they have several important biological activities, such as defense against microbial attacks and protection of plant tissues from being attacked by insects and herbivores due to their unflavored taste (Scalbert 1991). 
Tannins are uniquely characterized from other phenolic compounds by their ability to precipitate proteins from solutions to other macromolecules such as starch, cellulose, and minerals through formation of strong complexes with them (Lekha and Lonsane 1997; Aguilar et al. 2007). This property is the major source of tannin's undesirable effects in nutrition. Their ability to bind to macromolecules including proteins and minerals prevents their digestion and absorption and leads to inhibition of digestive enzymes (RodríguezDurán et al. 2011). Moreover, tannins are responsible for the astringent and bitter taste of fruits, juices and wines which reduces the food intake. In addition, the consumption of large amounts of tannin is associated with development of some forms of cancer (Jana et al. 2014). However, the consumption of low concentrations of tannin in feed is associated with an increase in nitrogen assimilation in ruminants showing higher growth rates and milk production (Belmares et al. 2004; Aguilar et al. 2007). When ingested, tannin can prevent diarrhea, inflammation, diuretics and cancer. In addition, they can be used for the treatment of poisoning caused by heavy metals due to their metal chelating capacity. Moreover, they are considered as potent antimicrobial agents (Jana et al. 2014).

For confirmation of OP tannin degradation by $K$. marxianus fermentation and release of gallic acid in the fermented medium, both UFOP and FOP filtrates were subjected to HPLC analysis. It is well-known that HPLC analysis is very efficient in demonstrating differences in chemical constituents of samples. HPLC profile of OP tannin bioconversion to gallic acid by $K$. marxianus fermentation is shown in Fig. 1a-c. Figure 1a represents the HPLC pattern of tannic acid and gallic acid standards. HPLC profile of UFOP and FOP is shown in (Fig. 1b, c) . Using tannic acid and gallic acid as standards, HPLC data analysis showed revealed that tannic acid concentration in UFOP represented $1154.0 \mu \mathrm{g} / \mathrm{gds}$, while in FOP, tannic acid represented $37.49 \mu \mathrm{g} / \mathrm{gds}$. Also, gallic acid concentration in FOP was equal to $61.0 \mu \mathrm{g} / \mathrm{gds}$ comparing to $21.57 \mu \mathrm{g} /$ gds in UFOP. From these results, it can be concluded that $96.75 \%$ of total tannins contained in UFOP were hydrolyzed and degraded producing gallic acid increasing its concentration by 2.8 times as a result of $K$. marxianus fermentation (Fig. 1a-c). The degradation of OP tannin during fermentation by $K$. marxianus can be attributed to the secretion of tannase enzyme produced when OP was used as a sole carbon source for solid state cultivation of K. marxianus (Fathy et al. 2017).

\section{Conclusion}

Regarding the reduction of tannin content and the increase of gallic acid concentration in addition to the positive effect of fermentation on the chemical composition of OP through increasing protein, carbohydrate and energy contents with decreasing fiber content, SSF of OP by K. marxianus is considered as a suitable technique for bioconversion of OP into a value-added animal feed. However, further research work is necessary to optimize the improvement of the chemical composition and to verify the effectiveness of this degraded substrate on the performance of live animals.

Acknowledgements This work was supported by the National Research Centre, Egypt (Project No. 11010343).

\section{Compliance with ethical standards}

Conflict of interest The authors declare that they have no conflict of interest.

Open Access This article is distributed under the terms of the Creative Commons Attribution 4.0 International License (http://creativeco mmons.org/licenses/by/4.0/), which permits unrestricted use, distribution, and reproduction in any medium, provided you give appropriate credit to the original author(s) and the source, provide a link to the Creative Commons license, and indicate if changes were made.

\section{References}

Abu-Zreig M, Al-Widyan M (2002) Influence of olive mills solid waste on soil hydraulic properties. Commun Soil Sci Plant Anal 33:505517. https://doi.org/10.1081/CSS-120002760

Aguilar CN, Rodríguez R, Gutiérrez-Sánchez G et al (2007) Microbial tannases: advances and perspectives. Appl Microbiol Biotechnol 76:47-59. https://doi.org/10.1007/s00253-007-1000-2

Aliakbarian B, Casazza AA, Perego P (2011) Valorization of olive oil solid waste using high pressure-high temperature reactor. Food Chem 128:704-710. https://doi.org/10.1016/j.foodc hem.2011.03.092

Al-Masri M, Guenther K (1999) Changes in digestibility and cell-wall constituents of some agricultural by-products due to gamma irradiation and urea treatments. Radiat Phys Chem 55:323-329. https ://doi.org/10.1016/S0969-806X(98)00333-8

AOAC (1997) Analysis of the association of official analytical chemists, 17th edn. AOAC, Washington, D.C.

Azbar N, Bayram A, Filibeli A, Muezzinoglu A, Sengul F, Ozer A (2004) A review of waste management options in olive oil production. Crit Rev Environ Sci Technol 34:209-247. https:// doi.org/10.1080/10643380490279932

Belmares R, Contreras-Esquivel JC, Rodríguez-Herrera R, Coronel ARR, Aguilar CN (2004) Microbial production of tannase: an enzyme with potential use in food industry. Food Sci Technol 37:857-864. https://doi.org/10.1016/j.lwt.2004.04.002

Blaxter KL (1968) The energy metabolism of ruminants, 2nd edn. Spring field, Illinois

Borja R, Raposo F, Rincón B (2006) Treatment technologies of liquid and solid wastes from two-phase olive oil mills. Grasas Aceites 57:32-46. https://doi.org/10.3989/gya.2006.v57.i1.20

Brlek T, Voća N, Krička T, Lević J, Vukmirović Đ, Čolović R (2012) Quality of pelleted olive cake for energy generation. Agric Conspec Sci 77:31-35

Christoforou E, Fokaides PA (2016) A review of olive mill solid wastes to energy utilization techniques. Waste Manag 49:346-363. https ://doi.org/10.1016/j.wasman.2016.01.012

Cossu A, Degl'Innocenti S, Cristani M, Bedin S, Nuti M (2013) Assessment of the life cycle environmental impact of the olive 
oil extraction solid wastes in the european union. Open Waste Manag J 6:12-20. https://doi.org/10.2174/1876400220131014001

Dermeche S, Nadour M, Larroche C, Moulti-Mati F, Michaud P (2013) Olive mill wastes: biochemical characterizations and valorization strategies. Process Biochem 48:1532-1552. https://doi. org/10.1016/j.procbio.2013.07.010

Doymaz I, Gorel O, Akgun N (2004) Drying characteristics of the solid by-product of olive oil extraction. Biosyst Eng 88:213-219. https ://doi.org/10.1016/j.biosystemseng.2004.03.003

Dubois M, Gilles KA, Hamilton JK, Rebers P, Smith F (1956) Colorimetric method for determination of sugars and related substances. Anal Chem 28:350-356. https://doi.org/10.1021/ac60111a017

Fadel M, El-Ghonemy DH (2015) Biological fungal treatment of olive cake for better utilization in ruminants nutrition in Egypt. Int $\mathbf{J}$ Recycl Org Waste Agric 4:261-271. https://doi.org/10.1007/s4009 3-015-0105-3

Fathy SA, Rashad MM, Ezz MK, Mohammed AT, Mahmoud AE (2017) Enhanced tannase production by Kluyveromyces marxianus NRRL Y-8281 under solid state fermentation of olive oil cake. Res J Pharm Biol Chem Sci 8:1698-1708

Goering HK, Van Soest PJ (1970) Forage fiber analysis (apparatus, reagents, procedure and some applications). Agric Handb 379:20

Jahromi M, Liang J, Rosfarizan M, Goh YM, Shokryazdan P, Ho Y (2011) Efficiency of rice straw lignocelluloses degradability by Aspergillus terreus ATCC 74135 in solid state fermentation. Afr J Biotechnol 10:4428-4435. https://doi.org/10.5897/AJB10.2246

Jana A, Halder SK, Banerjee A, Paul T, Pati BR, Mondal KC, Mohapatra PKD (2014) Biosynthesis, structural architecture and biotechnological potential of bacterial tannase: a molecular advancement. Bioresour Technol 157:327-340. https://doi.org/10.1016/j.biort ech.2014.02.017

Kavdir Y, Killi D (2008) Influence of olive oil solid waste applications on soil $\mathrm{pH}$, electrical conductivity, soil nitrogen transformations, carbon content and aggregate stability. Bioresour Technol 99:2326-2332. https://doi.org/10.1016/j.biortech.2007.05.034

Lafka T-I, Lazou AE, Sinanoglou VJ, Lazos ES (2011) Phenolic and antioxidant potential of olive oil mill wastes. Food Chem 125:9298. https://doi.org/10.1016/j.foodchem.2010.08.041

Lekha P, Lonsane B (1997) Production and application of tannin acyl hydrolase: state of the art. In: Neidleman SL, Laskin AI (eds) Advances in applied microbiology, 44th edn. Elsevier Science, Amsterdam, pp 216-260

Lopes D, Pinho I, Santos S, Martins R, Quina M (2016) Germination index as a tool to assess phytotoxicity of olive mill solid wastes. In: 4th international conference on sustainable solid waste management. 23-25 June, Cyprus

López-Piñeiro A, Albarrán A, Nunes JR, Peña D, Cabrera D (2011) Long-term impacts of de-oiled two-phase olive mill waste on soil chemical properties, enzyme activities and productivity in an olive grove. Soil Tillage Res 114:175-182. https://doi.org/10.1016/j. still.2011.05.002

Molina-Alcaide E, Yáñez-Ruiz D (2008) Potential use of olive byproducts in ruminant feeding: a review. Anim Feed Sci Technol 147:247-264. https://doi.org/10.1016/j.anifeedsci.2007.09.021

Neifar M, Jaouani A, Ayari A et al (2013) Improving the nutritive value of olive cake by solid state cultivation of the medicinal mushroom Fomes fomentarius. Chemosphere 91:110-114. https ://doi.org/10.1016/j.chemosphere.2012.12.015

NRC (1977) National Research Council. Nutrient requirements of rabbits, National Academy of Science, Washington, D.C., USA
Nunes MA, Pimentel FB, Costa AS, Alves RC, Oliveira MBP (2016) Olive by-products for functional and food applications: challenging opportunities to face environmental constraints. Innov Food Sci Emerg Technol 35:139-148. https://doi.org/10.1016/j.ifset .2016.04.016

Pandey A (1991) Aspects of fermenter design for solid-state fermentations. Process Biochem 26:355-361. https://doi.org/10.1016/00329592(91)85026-K

Ramachandran S, Singh SK, Larroche C, Soccol CR, Pandey A (2007) Oil cakes and their biotechnological applications-a review. Bioresour Technol 98:2000-2009. https://doi.org/10.1016/j.biort ech.2006.08.002

Rodríguez-Durán LV, Valdivia-Urdiales B, Contreras-Esquivel JC, Rodríguez-Herrera R, Aguilar CN (2011) Novel strategies for upstream and downstream processing of tannin acyl hydrolase. Enzyme Res 2011:1-20. https://doi.org/10.4061/2011/823619

Scalbert A (1991) Antimicrobial properties of tannins. Phytochemistry 30:3875-3883. https://doi.org/10.1016/0031-9422(91)83426-L

Uribe E, Lemus-Mondaca R, Vega-Gálvez A et al (2013) Quality characterization of waste olive cake during hot air drying: nutritional aspects and antioxidant activity. Food Bioprocess Technol 6:1207-1217. https://doi.org/10.1007/s11947-012-0802-0

Uribe E, Lemus-Mondaca R, Vega-Gálvez A, Zamorano M, QuispeFuentes I, Pasten A, Di Scala K (2014a) Influence of process temperature on drying kinetics, physicochemical properties and antioxidant capacity of the olive-waste cake. Food Chem 147:170-176. https://doi.org/10.1016/j.foodchem.2013.09.121

Uribe E, Lemus-Mondaca R, Pasten A, Astudillo S, Vega-Gálvez A, Puente-Díaz L, Di Scala K (2014b) Dehydrated olive-waste cake as a source of high value-added bioproduct: drying kinetics, physicochemical properties, and bioactive compounds. Chil J Agric Res 74:293-301. https://doi.org/10.4067/S0718-58392 014000300007

Uribe E, Pasten A, Lemus-Mondaca R, Vega-Gálvez A, QuispeFuentes I, Ortiz J, Di Scala K (2015) Comparison of chemical composition, bioactive compounds and antioxidant activity of three olive-waste cakes. J Food Biochem 39:189-198. https:// doi.org/10.1111/jfbc. 12120

Van Soest PV, Robertson J, Lewis B (1991) Methods for dietary fiber, neutral detergent fiber, and non-starch polysaccharides in relation to animal nutrition. J Dairy Sci 74:3583-3597. https://doi. org/10.3168/jds.S0022-0302(91)78551-2

Vera R, Aguilar C, Pérez Meléndez P et al (2009) Feeding dry olive cake modifies subcutaneous fat composition in lambs, noting cake resistance to degradation and peroxidation. Chil J Agric Res 69:548-559. https://doi.org/10.4067/S0718-58392009000400010

Weinberg Z, Chen Y, Weinberg P (2008) Ensiling olive cake with and without molasses for ruminant feeding. Bioresour Technol 99:1526-1529. https://doi.org/10.1016/j.biortech.2007.04.022

Wickerham LJ (1951) Taxonomy of yeasts, 1029th edn. United States Department of Agriculture Technical Bulletin, Washington, pp $1-56$

Publisher's Note Springer Nature remains neutral with regard to jurisdictional claims in published maps and institutional affiliations. 